\title{
Introductory placement tests of students with primary school teacher major in Hungary
}

\author{
Bagota, Mónika ${ }^{1}$, Csíkos, Csaba ${ }^{1}$ \& Szitányi, Judit ${ }^{1}$ \\ ${ }^{1}$ ELTE Faculty of Primary and Pre-School Education
}

\begin{abstract}
In the academic year of 2016/17, the Department of Mathematics at the ELTE Faculty of Primary and Pre-School Education (Budapest) has introduced a new, Mathematics Primer Course for first-year students majoring in primary school education. Since this year, every first-year student to enrol has taken a compulsory placement test in Mathematics. Our supposition from this was that the students who attain weaker results do not have poorer abilities, but rather suffer lacks in their factual knowledge. Moreover, they do not possess adequate experience or skills in how best to apply their knowledge to an exact problem. By reviewing the methods and techniques to be applied when solving the placement test, we can deduce which topics demand greater emphasis in the future.
\end{abstract}

Keywords: Mathematics, placement tests, primary school teacher major

\section{Introduction}

Supporting the process of becoming an educator also means developing the views, knowledge, abilities, practical skills, devotion and attitudes held by pre-service elementary teachers in Hungary (Falus, 2004). Moreover, the factual knowledge among these, which the pedagogues will use later during their teaching career, is essential and not negligible at all. As regards the subject of Mathematics, The Hungarian National Curriculum formulates the following expectations:

Developing a confident level of counting skills is of utmost importance among the fields of mathematical literacy. The development of communication is also important (reading comprehension, listening and understanding of the ideas of others communicated in written or oral form, the expression of one's own ideas), the ability of debating based on arguments.

It is essential in the mathematical development and learning process of pupils to be able to choose and apply the models, the ways of thinking and different methods that describe various natural and social phenomena. 
It is similarly important to develop those abilities which help to reach decisions regarding the scope and practical application of the models. It is also necessary to experience and learn the reproductive, problem-solving, creative way of thinking, while gaining a level of automaticity in basic activities (e.g. measurement), mathematical operations (e.g. arithmetical, algebra operations, transformations) is not to be neglected either.

There is a need for Mathematics teachers who are well-trained methodologically and possess sufficient mathematical knowledge to fulfil the goals formulated in the National Curriculum. Given the current tendencies, it is especially important to realise that the most important prerequisite in creating a well-working educational system is to ensure a high standard of teacher training (Barber, \& Mourshed, 2007). To this end, it is not only essential for future educators to undergo thorough and comprehensive preparation, but also to filter those whose mathematical knowledge displays gaps and subsequently help them address these weaknesses. By doing so, it is our hope that the elementary teachers' training program at the Faculty of Primary and Pre-School Education will be more united as regards both the work of our professors and the students' academic progress.

With a view toward addressing the aspects mentioned above, in the academic year of 2016/17 the Department of Mathematics of the ELTE Faculty of Primary and Pre-School Education (Budapest) introduced a new, Mathematics Primer Course for first-year students majoring in primary education. In Hungary, entrance to the Faculty is precluded by an eligibility exam in speaking, music and physical aptitude; no mathematical eligibility exam is required prior to entering teacher training. Therefore, all accepted students must sit for an introductory levelling test before the start of the autumn semester. Every student who enrols for the first year has had to sit for the compulsory placement test since $2016 / 2017$. The exams occur at two dates and under the same conditions. The students have seventy minutes to solve the test without usage of a calculator or any other aid. From 2016/17 to 2019/20, a total of 824 students have participated in this exam.

Open-ended mathematical tasks are customarily assigned to students in Hungary's secondary schools; this type of exercise is also a common feature of the maturation exam that all students must take at the end of their secondary school studies. In order to ensure and enhance objectivity while attaining the most information within the given time constraints (covering each important mathematical topics within the narrow time limit), we also introduced multiple-choice tasks to the Mathematics Primer test. Consisting of two parts every year, the test contains twenty test exercises and four problems that require detailed solutions. All of the test exercises were multiplied choice tests with four possible given answers out of which only one was correct. Among the possible answers there are some that may appear correct due to weak counting ability, poor comprehension, or a lack of mathematical knowledge among first-year students. Moreover, all test exercises are worth one point, thus 20 points can be gained. Since the four 
problems demanding detailed solutions contain five items, the overall test score equals 40 points. (During the academic year of 2016/17, the problems requiring detailed solutions consisted of four items, therefore the results of these exercises were examined from the next term and regarded 591 students.)

In our opinion, only the students who genuinely need to refresh their mathematical knowledge should attend the Mathematics Primer Course. Thus, we formulate the student groups for this course according to their levelling test results. The Primer Course has to be taken by those students whose results did not reach $50 \%$ at the introductory levelling test. Within the full-time students training to become primary teachers, generally two courses are offered, with thirty participants each. One Primer Course is available to correspondence students, of whom 15 can register. Beginning in 2016/17, this remedial training course lasts thirteen weeks and consists of forty-five-minute lessons held once per week for full-time students. Correspondence students complete $60 \%$ of the worksheets during three contact occasions under the direction of teachers; the remaining tasks are assigned as individual work for them.

Based on the National Curriculum and Framework, the topics that form a part of the training include the following:

- Writing numbers, neighbour numbers, rounding off

- Division with remainders, divisibility, greatest common divisor, least common multiple

- Fractions

- Order of arithmetical operations, algebraic transformations, open sentences

- Simple logical exercises

- Simple combinatorial tasks

- Conversions of length, volume, weight and time measures

- Geometry (plane figures, calculating the area and the perimeter; characteristics of solid shapes)

At each lesson, we teach students the material for a given theoretical topic by means of exact exercises (Bagota, 2019). The worksheets contain an average of 15-20 exercises, which the students complete together during the lessons. Another part of the exercises is done individually as homework. Apart from the continuous teacher consultation, the students - whether full-time or attending correspondence courses - receive the solutions for all the exercises in electronic form. At the end of the course, the students take another test containing twenty-four questions in order to ascertain their acquired knowledge. The structure of the test is identical to the structure of the introductory test and contains twenty multiple-choice test questions and four open-ended answer exercises. Based on our current experience, these remedial lessons are successful: by using this method and these exercises, students reach a result of $90 \%$ on the follow-up test. A detailed study discusses the results of first-year students for 2016/17 (Dancs, Kulman, \& Pintér, 2017); moreover, we have also compared the results of firstand third-year students for 2016/17 (Bagota, \& Szitányi, 2018). 


\section{Methods}

Due to the fact that our exercises mainly tested the knowledge (or lack thereof) required for primary school, we designed the arrangement of exercises that both most of the simpler and the more complicated ones were word problems. Our choice was determined by our experience regarding how the different strategies of solutions for word problems are not conscious for students (Csíkos, Szitányi, \& Kelemen, 2012). “The work with word problems has two main functions at the lower division of school. One function is concerning the understanding of mathematical operations. The other function is concerning the development of problem-solving thinking, making a question mathematical, creation of models" (C. Neményi, \& R. Dr. Szendrei, 2010: 213). We also made sure that there would be exercises among the chosen ones which

- have a model of counting exercise or open sentence;

- the solution is one or two numbers, a pair of numbers, or data;

- the answer can be retrieved in one or more steps;

- the formulation is straight in text, or reverse (C. Neményi, \& R. Dr. Szendrei, 2010: 239).

In Hungary the National Core Curriculum summarises the mathematical competence for forms 1-4 in elementary schools as the following (1068810707):

The pupil is able to sense the place, size of objects in relation to each other, able to navigate in three and two dimensions as well. The pupil discovers the relationship between quantities according to his or her experiences, and able to formulate these experiences. The pupil is able to do simple measurements, able to express the results with the learnt units of quantities. He or she is able to recall and use mathematical algorithms during practical activities. The pupil can count in his or her head in the scope of 1000. He or she can decide the verity of simple statements, realises simple logical relations.

In adherence to the expectations of the National Curriculum and Framework, we select the tasks for the test so that all of the exercises belong to one of the four categories mentioned below:

- comprehension

- concept of number, mathematical operations

- measuring

- context understanding.

On the test, all four categories contain five exercises in order to fulfil our aim of representing the developmental categories emphasised during the lower division of primary school. 
Sample exercises of each of the four categories:

\section{Comprehension}

Gerry and Helga have 158 marbles altogether. Gerry has 30 more than Helga. How many marbles does Helga have?
(A) 64
(B) 128
(C) 94
(D) 109

Concept of number, mathematical operations

How many is the sum of the following amount:

27 tens +32 thousands +85 ones +19 hundreds?
(A) 32192785
(B) 3311155
(C) 34255
(D) 33155

This exercise requires not only accurate way of writing the digits in the decimal number system, but also checks the correct calculation (Csíkos, 2016).

\section{Measuring}

Mary cuts 35-centimetre-long ribbons from a 17-meter reel to wrap eight presents. How long is the ribbon that is left on the reel?
(A) $135 \mathrm{~cm}$
(B) $1420 \mathrm{~cm}$
(C) $142 \mathrm{~cm}$
(D) $14 \mathrm{~m} 2 \mathrm{~cm}$

\section{Context understanding}

One license plate for each of three cars is removed. How many ways is it possible to take back all three so that exactly one number plate returns to its original place?
(A) 1
(B) 3
(C) 6
(D) 10

We used Version 16 of the IBM SPSS program package and the 2016 version of Microsoft Excel to calculate the results; our hypotheses were tested on a test of $5 \%$ significance. All of the test exercises are used to assess the students' simple mathematical problem-solving ability and knowledge. The inner consistence of the whole test is acceptably high (See Figure 1).

\begin{tabular}{|c|c|c|}
\hline Year & N & $\begin{array}{c}\text { Cronbach's } \boldsymbol{\alpha} \\
\text { (20 multiple-choice items and four open-ended tasks) }\end{array}$ \\
\hline 2016 & 233 & 0,74 \\
\hline 2017 & 204 & 0,76 \\
\hline 2018 & 236 & 0,86 \\
\hline 2019 & 220 & 0,79 \\
\hline
\end{tabular}

Figure 1

Note: In 2016, reliability is calculated without the open-ended tasks 
The obtained results were as follows (See Figure 2)

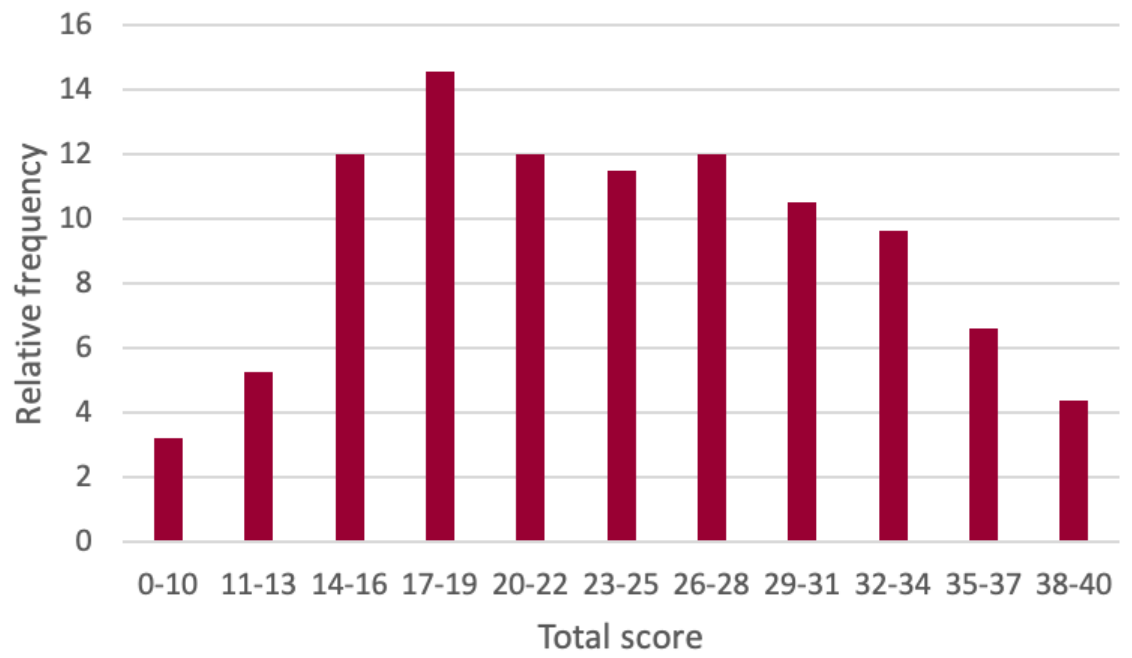

Figure 2

Distribution of levelling test points

We viewed the average result (23.62 points, $59.05 \%$ ) as a markedly low one since the tasks were made to suit pupils who had finished the fourth form in elementary school. In the case of multiple-choice test exercises, the average is a bit better (13.93 points, $69.65 \%)$. The result falls due to the open-ended answer exercises, tasks that demand more intellectual steps and planning (9.9 points, $49.5 \%)$. It can be observed in the attached frequency diagrams that while in the case of multiply choice test exercises the dispersion slants strongly toward the right direction, it is more balanced in the case of open-ended answer exercises (See Figure 3). This also suggests that our students' largest challenge is to work out and conduct complex solving plans, even if they are able to solve separate parts of the exercise. Of course, successfully solving the test and the open-ended answer exercises are not independent from each other given that the relation is of medium strength. All correlation coefficients are significant at the $\mathrm{p}<.001$ level. 


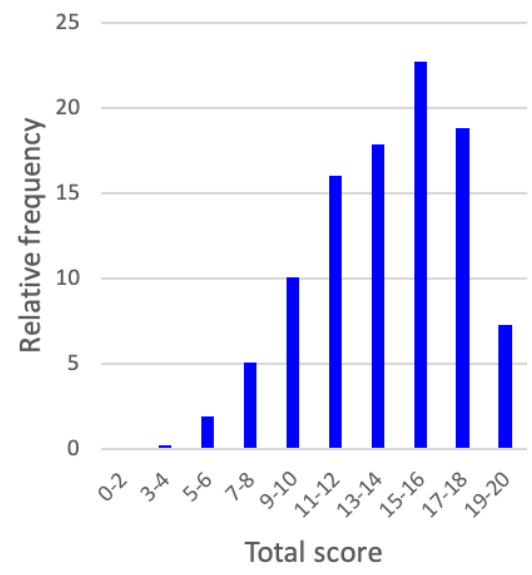

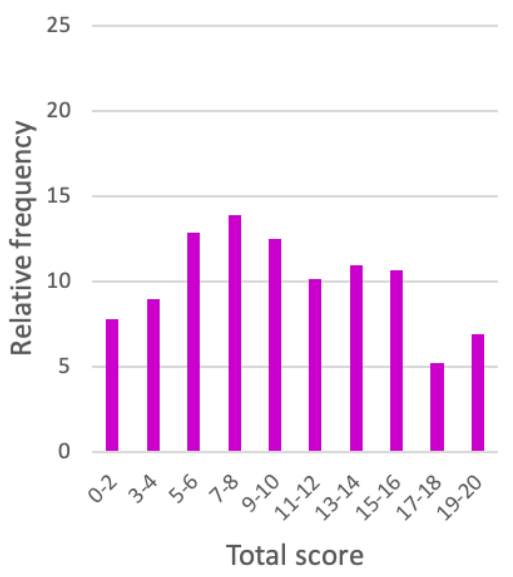

Figure 3

Distribution of multiple-choice items; Distribution of open-ended tasks

The analysis of the four types of exercises shows that the students solve the tasks on the topic of measuring above $72 \%$ success and are able to solve exercises regarding place-value number systems when adding above ten. Nor did tasks requiring simple, direct thinking pose a challenge (See Figure 4). The students who fall into the low quartile are most successful at exercises that can be solved graphically (by drawing) and exercises that demand interpreting the place-value number system. However, the results of our students fall below $67 \%$ in cases when the task requires inverse thinking, a formula is needed for the solution, or the definition of a certain exact mathematical concept has to be used. We found that the exercise that causes problems even for students who generally attained high scores is the type with context understanding: for example, a ranking exercise that cannot be solved by formula, or a word problem exercise where there are unknowns on both sides to be solved via a formula. Exercises requiring the interpretation of exact mathematical concepts also posed difficulties as the results garnered by this kind of task are under $66 \%$. The explanation of this phenomenon may be that these types of exercises usually cannot be easily solved when relying upon drilled-in practice; solving them necessitates a slightly different kind of thinking, or leads to some mathematical function. The conclusion we drew from this was that students with weaker results do not lack abilities, but rather exhibit gaps in their factual knowledge. Furthermore, when it comes to applying their knowledge in the case of an exact problem, their skills are not appropriate. 


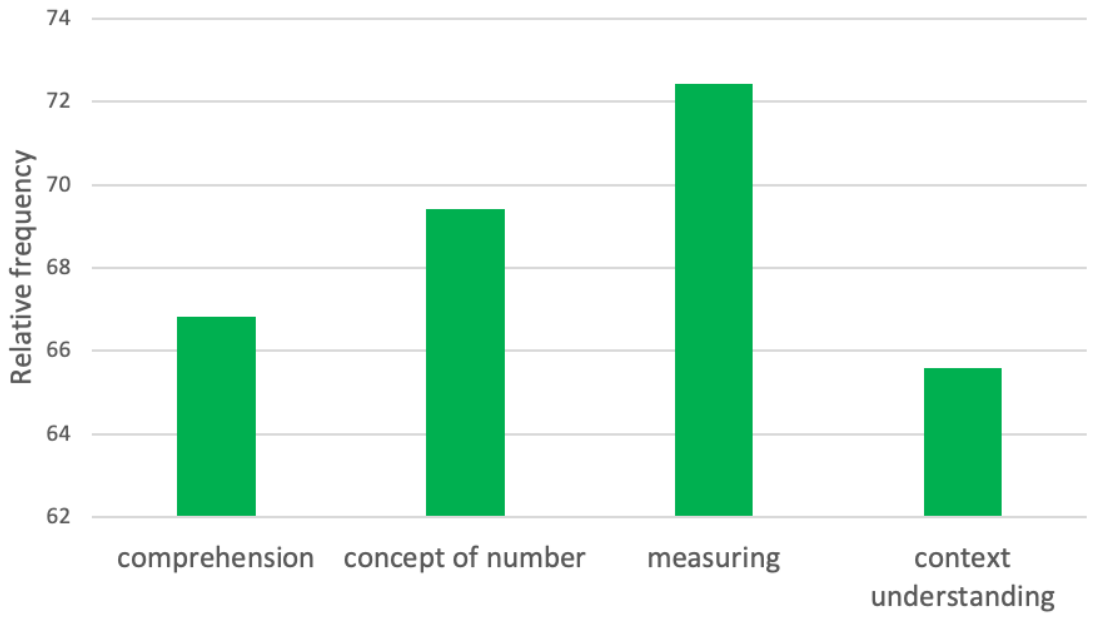

Figure 4

Distribution of points in the 4 types of the multiple-choice items

The presentation of the wrong solution to the following open-ended answer exercise also implies that there are serious problems concerning exercises involving the interpretation of exact mathematical concepts in the case of several students.

Exercise: We divided a square by lines parallel to one of its sides into four, congruent narrow rectangles. Each of these rectangles' perimeters is $30 \mathrm{~cm}$. What is the perimeter of the whole square?

Not only is it obvious that the student knows the formula of calculating the perimeter of the rectangle, it can also be seen based on the second formula that he or she interprets the first sentence of the exercise well (See Figure 5). However, from this point on, our experience seems to be confirmed that the application of the different problem-solving strategies concerning word problems is not a conscious process for the students (Csíkos, Szitányi \& Kelemen, 2012). In other words, the student used the right formula, but deducted the area of the rectangle (this is shown by the applied $30 \mathrm{~cm}^{2}$ instead of $30 \mathrm{~cm}$ ), and the incorrect solution emerges from this misstep. In this case we think that the student was not aware that he or she should have taken into consideration the length of the line bordering the small rectangle in the exercise in order to calculate the line bordering the square. 


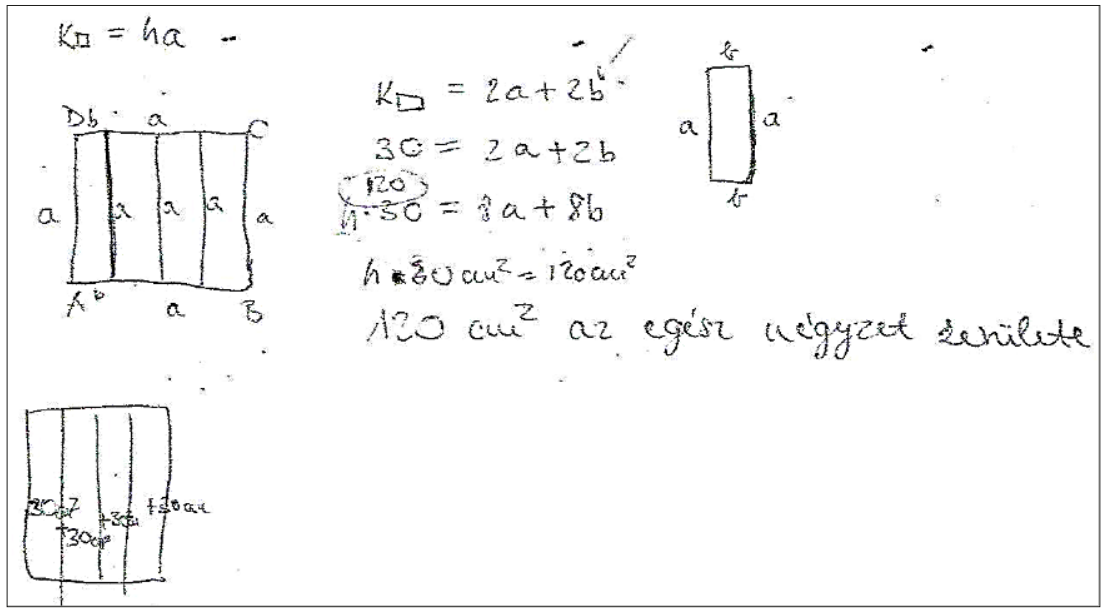

Figure 5

\section{Summary}

Based on the results of the survey, we can state that the lack of knowledge in the case of the students displaying weaker results mainly originated from a lack of knowledge of mathematical concepts, including problem-solving strategies and the application of their already extant knowledge. These students can now hopefully be aided with a targeted program in remedial education; we therefore view our initiative in starting our Mathematics Primer Course justified.

Upon reviewing the methods and techniques to be applied when solving the placement test, we can deduce the tasks that demand greater emphasis in the future (Ambrus, 2004). According to our opinion, further development can be achieved, when we place a stronger emphasis on the learning and teaching of practical knowledge in the curriculum, thereby allowing our students to acquire a deeper knowledge of the problem-solving techniques, methods needed for the lower division of primary school. Our training will furthermore have a positive effect on developing our students' competencies in problem-solving.

Our plan is to have graduating students retake the eligibility test; for our students who started the program in the academic year, 2016/17, this test will be due this semester. By comparing their results, not only will our department gain access to new research data, we will also be able to assess the long-term effectiveness of our courses and further tailor our methods and approach to suit the needs of future primary teachers. 


\section{Reference}

Ambrus, G. (2004). A gyakorlás újfajta értelmezése a matematikadidaktikában és a matematikatanárok képzésében. [A new approach to practice and exercise in mathematics education and in mathematics teacher training.] A Matematika Tanítása, 12(3), 10-15.

Bagota, M. \& Szitányi, J. (2018). Tanító szakos hallgatók matematikai ismereteinek szintfelmérése. [Level testing of first year elementary pre-service teachers.] Képzés és gyakorlat, 16(1), 63-72.

https://doi.org/10.17165/TP.2018.1.7

Bagota, M. (2019). Matematikai praktikum. Feladatgyüjtemény tanítóknak. [Mathematical practicum. Task collection for elementary teacher.] ELTE Reader. http://www.eltereader.hu/kiadvanyok/bago ta-monika-matematikai-praktikumfeladatgyujtemeny-tanitoknak/ (2020.01. 10.)

Barber, M. \& Mourshed, M. (2007). How the world's best performing school systems come out on top. McKinsey \& Company.

https://www.mckinsey.com/ /media/mckinsey/industries/social\%20sector/ our\%20insights/how\%20the\%20worlds\%20best\%20performing\%20school\%20 systems\%20come\%20out\%20on\%20top/how_the_world_s_best-performing school_systems_come_out_on_top.ashx (2020.01. 10.)

C. Neményi, E. \& Szendrei, J. (2010). A számolás tanitása. Szöveges feladatok. ELTE Eötvös Kiadó.

Csíkos, Cs. (2016). Strategies and performance in elementary students' three-digit mental addition. Educational Studies in Mathematics, 91(1), 123-139. https://doi.org/10.1007/s10649-015-9658-3

Csíkos, Cs., Szitányi, J. \& Kelemen, R. (2012). The effects of using drawings in developing young children's mathematical word problem solving: A design experiment with third grade Hungarian students. Educational Studies in Mathematics, 81(1), 47-65. https://doi.org/10.1007/s10649-011-9360-z

Dancs, G., Kulman, K. \& Pintér, M. (2017). Elsőéves tanítóképzős hallgatók matematikai képességfelmérésének eredményei. In Karlovitz, J. T. (Ed.), Válogatott tanulmányok a pedagógiai elmélet és szakmódszertanok köréból. [Results of firstyear elementary pre-service teachers on entrance level test. 228-235.

http://www.irisro.org/pedagogia2017januar/52DancsGabor-KulmanKatalinPinterMariann.pdf (2020. 01. 10.)

Falus, I. (2004). A pedagógussá válás folyamata [The process of becoming an educator]. Educatio, 13(3), 359-374.

Kerettanterv az általános iskola 1-4. évfolyamára [Frame Curriculum for Grades 1 to 4] http://kerettanterv.ofi.hu/01_melleklet_1-4/index_alt_isk_also.html (2020.01. 10.)

Nemzeti alaptanterv 2012. Matematika [National Core Curriculum 2021 Mathematics] 
https://ofi.oh.gov.hu/sites/default/files/attachments/mk_nat_20121.pdf (2020. 01. 10.)

http://docplayer.hu/16223946-Nemzeti-alaptanterv-2012-matematika.html (2020. 01. 10.)

https://doi.org/10.15520/ijnd.v10i06.2942

Mónika Bagota: https://orcid.org/0000-0001-9203-3552

Csaba Csíkos: https://orcid.org/0000-0003-3328-5535

Judit Szitányi: https://orcid.org/0000-0003-3266-5966 